\title{
EFL Teachers' Perceptions of Learner Autonomy and Their Classroom Practices: A Case Study
}

\author{
Tham My Duong
}

\author{
Suranaree University of Technology, Nakhon Ratchasima 30000, Thailand
}

\begin{abstract}
It is considered that learner autonomy places a great emphasis on learners' role as independent learners who are able to take control over their learning. That is not to say, teachers become redundant in a classroom. In contrast, the key role of the teacher is to create and maintain learning community. Accordingly, this study attempted to investigate EFL teachers' perceptions of the promotion of learner autonomy and their teaching practices in a Thai context. It was quantitative-focused research, so data were obtained via a closed-ended questionnaire. The participants consisted of thirty EFL teachers who were teaching English at a Thai university. For data analysis, descriptive statistics and Wilcoxon signed ranks test were employed. The results showed that the participants could perceive the concept of learner autonomy and roles of teachers in autonomous language learning, yet most of them found it difficult to apply their knowledge about learner autonomy in this context. It is hoped that these preliminary findings partly contribute to literature regarding the promotion of learner autonomy in an EFL context.
\end{abstract}

Index Terms: Learner autonomy; Perceptions; EFL teachers; Classroom practices

(C) 2014 Published by MECS Publisher. Selection and/or peer review under responsibility of the Research Association of Modern Education and Computer Science.

\section{Introduction}

Within the changing landscape of English language teaching in the $21^{\text {st }}$ century, the concept of learner autonomy is believed to be important since it is seen as the goal of all developmental learning [7], [8]. It is due to the fact that the rapid technological development somehow leads to changes in the society, particularly in education. Inevitably, it provides learners with freedom for their learning.

With reference to the concept of learner autonomy, it is found that learner autonomy is variously defined by scholars [5], [11]. Holec's (1981) definition (as cited in [9]) which states that learner autonomy is an "ability to take charge of one's own learning" (p. 193) has been seen as one of the most widespread definitions. It refers to learners' self-management of learning [5]. In another aspect, according to Scharle and Szabó [11], learner

* Corresponding author. Tel.: +66 882405004

E-mail address: duongmythamav@yahoo.com 
autonomy might be fostered if learners are able to take responsibility for and make decisions about their learning.

Meanwhile, Benson (2001) argues that self-management and a sense of responsibility in language learning are two aspects of the nature of autonomy. He then presents three clearly interdependent aspects: learning management, cognitive process, and learning content, which are included in the definition that learner autonomy is "the capacity to take control of one's own learning" (p. 47). He claims that a learner can control learning methods but not learning content, s/he may fail to be a fully autonomous learner. This paper views Benson's (2001) definition as an operational definition. In other words, to become an autonomous learner, s/he should possess the following abilities, namely the ability to self-manage their learning, the ability to take responsibility for their own learning, and the ability to take control of learning content.

The concept of learner autonomy is basically unstable. Hence, there have been various studies [5], [9], [11] addressing categories of levels of learner autonomy relatively differently. Of these categories, Nunan's (1997) category is quite closely related to the purpose of this paper inasmuch as it discusses learner autonomy within the framework of language learning with five levels. The first level involves the attempt to make learners aware of goals, strategies, and content of materials. The second level is to get learners involved in making choices from a variety of goals, content and strategies. The third level is to encourage learners to adapt and modify the goals and the content of the learning program. The next level is to let learners set their goals, develop their content and create learning tasks. The last level is for fully autonomous learners as they can make connections between the content of classroom learning and the world.

\section{Methodology}

\subsection{Research questions}

The aim of the study is to investigate teachers' perceptions of promoting learner autonomy and their teaching practices; thus, three research questions were formulated as follows:

1. What are EFL teachers' perceptions of the concept of learner autonomy?

2. What are the teachers' perceptions of necessity and feasibility of promoting learner autonomy in a Thai EFL context?

3. Do the teachers promote learner autonomy in this context? How frequently do the teachers use teaching activities in their classes?

\subsection{Setting of the study}

This study was conducted in a Thai university that is an autonomous university under the supervision of Royal Thai Government. School of Foreign Languages, belonging to Institute of Social Sciences, has been responsible for teaching English to all students who are required to take general English courses (English 1-5) as an obligatory part in their curriculum. Each course lasts thirteen weeks.

In a Thai university in which this study was carried out, several kinds of technologies (e.g., computers, the Internet, language laboratories, etc.) have been equipped for learning efficiency. To increase students' motivation, besides the textbook Four Corners, the digital teaching tool so-called Classware is used. It presents the full Student's book, plays audios, and shows videos. These extra exercises are designed for students to practice on their own.

\subsection{Participants}

The participants of this study included thirty EFL teachers who have been teaching English at the university where the current study was conducted. There were twenty-one females (70\%) and nine males (30\%) from four 
countries: China (6), Thailand (15), Vietnam (6), and USA (3). Regarding background on learner autonomy, all the respondents more or less knew about the concept of learner autonomy. Particularly, 39.3\% of the respondents took part in a coursework, training or conference of learner autonomy, and the others learned about learner autonomy because of their interest.

\subsection{Data collection and Data analysis}

Data were collected by a closed-ended questionnaire that was adapted from the questionnaires written by Borg and Al-Busaidi (2012) and Joshi (2011). It included three main parts: (1) teachers' understanding of learner autonomy, (2) their current teaching, and (3) necessity and feasibility of promoting learner autonomy. The internal reliability of the questionnaire calculated by Cronbach's alpha was at $\alpha=.77$. The questionnaire was sent out to the respondents and collected a week later. The data were then analyzed through descriptive statistics and Wilcoxon signed ranks test.

\section{Results and Discussion}

\subsection{EFL Teachers' Understanding of Learner Autonomy}

As noted earlier, this part of the questionnaire has two sub-parts: definition of learner autonomy and teacher role in promoting learner autonomy. First of all, the items concerning definition of learner autonomy were categorized into four groups: (i) 'decision-making ability' (items 1, 2 \& 3); (ii) 'learner independence' (items 4 \& 5); (iii) 'psychology of learning' (items 6, 7 \& 8) and (iv) 'levels of learner autonomy' (items 9, 10, 11, 12 \& $13)$.

Table 1. Teachers' understanding of learner autonomy

\begin{tabular}{|c|c|c|c|c|c|c|c|c|}
\hline \multirow{2}{*}{\multicolumn{2}{|c|}{ Items }} & \multicolumn{5}{|c|}{ Levels of agreement $(\%)(n=30)$} & \multirow{2}{*}{ Mean } & \multirow{2}{*}{ S.D. } \\
\hline & & 1 & 2 & 3 & 4 & 5 & & \\
\hline (1) & $\begin{array}{l}\text { Autonomy means that learners can make choices about how } \\
\text { they learn. }\end{array}$ & 0 & 6.7 & 16.7 & 43.3 & 33.3 & 4.03 & .89 \\
\hline (2) & $\begin{array}{l}\text { Learner autonomy is promoted when learners have some } \\
\text { choice in the kinds of activities they do. }\end{array}$ & 3.3 & 3.3 & 3.3 & 50 & 40 & 4.20 & .93 \\
\hline \multirow[t]{2}{*}{ (3) } & $\begin{array}{l}\text { Learner autonomy is promoted when learners can choose their } \\
\text { own learning materials. }\end{array}$ & 3.3 & 0 & 13.3 & 53.3 & 30 & 4.07 & .87 \\
\hline & & \multicolumn{3}{|c|}{ Total } & & & 4.10 & .73 \\
\hline (4) & $\begin{array}{l}\text { Learner autonomy requires learners to be entirely independent } \\
\text { of the teacher. }\end{array}$ & 20 & 60 & 6.7 & 10 & 3.3 & 2.17 & .99 \\
\hline \multirow[t]{2}{*}{ (5) } & $\begin{array}{l}\text { Learner autonomy is promoted by independent work in a self- } \\
\text { access centre. }\end{array}$ & 3.3 & 3.3 & 13.3 & 53.3 & 26.7 & 3.97 & .93 \\
\hline & & \multicolumn{3}{|c|}{ Total } & & & 3.07 & .67 \\
\hline (6) & $\begin{array}{l}\text { Learner autonomy is promoted when learners are free to decide } \\
\text { how their learning will be assessed. }\end{array}$ & 0 & 10 & 33.3 & 43.3 & 13.3 & 3.60 & .86 \\
\hline (7) & $\begin{array}{l}\text { Motivated language learners are more likely to develop learner } \\
\text { autonomy than learners who are not motivated. }\end{array}$ & 0 & 3.3 & 6.7 & 36.7 & 53.3 & 4.40 & .77 \\
\hline (8) & $\begin{array}{l}\text { Confident language learners are more likely to develop } \\
\text { autonomy than those who lack confidence. }\end{array}$ & 0 & 3.3 & 20 & 36.7 & 40 & 4.13 & .86 \\
\hline & & & Total & & & & 4.04 & .56 \\
\hline
\end{tabular}




\begin{tabular}{|c|c|c|c|c|c|c|c|c|}
\hline (9) & $\begin{array}{l}\text { Learner autonomy means that learners are aware of their own } \\
\text { learning (e.g., setting goals, developing strategies, and } \\
\text { determining content of materials). }\end{array}$ & 0 & 6.7 & 20 & 26.7 & 46.7 & 4.13 & .97 \\
\hline (10) & $\begin{array}{l}\text { Learner autonomy means that learners are involved in making } \\
\text { choices from a variety of goals, content, and strategies. }\end{array}$ & 3.3 & 0 & 10 & 56.7 & 30 & 4.10 & .85 \\
\hline (11) & $\begin{array}{l}\text { Learner autonomy means that learners can modify the goals } \\
\text { and the content of the learning program. }\end{array}$ & 0 & 13.3 & 20 & 43.3 & 23.3 & 3.77 & .97 \\
\hline (12) & $\begin{array}{l}\text { Learner autonomy means that learners can create their own } \\
\text { learning styles (e.g., setting goals, developing content of } \\
\text { materials, and creating learning tasks). }\end{array}$ & 0 & 16.7 & 20 & 33.3 & 30 & 3.77 & 1.07 \\
\hline (13) & $\begin{array}{l}\text { Learner autonomy means that learners can make connections } \\
\text { between the content of classroom learning and the world. }\end{array}$ & 0 & 20 & 3.3 & 43.3 & 33.3 & 3.90 & 1.09 \\
\hline & & & Total & & & & 3.93 & .74 \\
\hline
\end{tabular}

Note: 1: Strongly disagree; 2: disagree; 3: Undecided; 4: Agree; 5: Strongly agree; $n$ : Number of participants

As displayed in Table 1, the mean score of each group was quite high: 'decision-making ability' $(\overline{\mathrm{X}}=4.10)$, 'learner independence' ( $\overline{\mathrm{X}}=3.07)$, 'psychology of learning' $(\overline{\mathrm{X}}=4.04)$, and 'levels of learner autonomy' $(\bar{X}=3.93)$. This means that the participants understood the concept of learner autonomy in general because they mostly agreed with the statements. Yet, some items with low mean scores such as entire independence and selfassessment should be considered.

In respect of the group 'decision-making ability', all mean scores were higher than 4.0 which reflects 'agree'. It means that the participants gained quite good understanding of decision-making process regarding learning methods, kinds of activities, and learning materials in promoting learner autonomy. The results are in line with some previous studies [1], [4], [13] indicating that autonomous learners, according to teachers, should take part in decision-making process in language learning.

In relation to the group 'learner independence', the results demonstrated that $80 \%$ of the respondents agreed that learner autonomy may be promoted by independent work in a self-access center. That is, the participants thought that learner autonomy was associated with learner independence. However, most of them (80\%) disagreed that autonomous learners were entirely independent of the teacher, i.e., they did not believe that entire independence could help promote learner autonomy. This result is quite similar to Aoki and Smith's (1999) viewpoint that "autonomy does not entail total independence" (p. 22). In contrast, Benson (2001) argues that the term "full autonomy" is to "describe the situation in which the learner is entirely independent of teachers, institutions or specially prepared materials" (p. 13). In short, the mean score of this group was around 3.0 which reflects 'undecided'. It means that the participants seemed to be confused with these items. This may be concluded that autonomy means independence [5]; yet the degree of independence should be taken into consideration.

Regarding the group 'psychology of learning' in which affective factors and learners' evaluation of learning were included in the questionnaire, $90 \%$ of the respondents thought that motivated language learners were more likely to develop learner autonomy than learners who were not. This may lead to a conclusion that unmotivated condition may prevent the participants from promoting learner autonomy as found by Borg and Al-Busaidi (2012). For the statement relating to students' evaluation of their learning, although $33.3 \%$ of the respondents felt unsure about students' ability to evaluate their own learning, more than a half of the respondents (56.6\%) believed that students could get involved in learning assessment. Similarly, several researchers [5], [12], [13] ascertain that autonomous learners can evaluate their own learning or progress.

As far as the last group 'levels of learner autonomy' is concerned, as seen in Table 1, the mean score of each item was higher than 3.7. This means that the respondents possessed certain understanding of levels of learner autonomy. The results indicated that the participants could generally understand the levels of learner autonomy. According to Nunan (1997), language teachers should bear the knowledge of levels of learner autonomy in mind if they wish to create an autonomous learning environment. 


\subsection{Necessity and feasibility of promoting learner autonomy in this context}

Necessity and feasibility of promoting learner autonomy with the two-point scale in which 1 reflects 'necessary' or 'feasible' and 2 reflects 'unnecessary' or 'unfeasible' were compared through two sets of ideas. The first set focused on student involvement in decision-making process about the objectives of a course, the materials used, the kinds of tasks and activities they do, the topic discussed, the learning assessment, and the teaching methods used. The second was about students' ability in monitoring their learning process (i.e., identifying their own needs, monitoring their progress, evaluating their own learning, learning cooperatively, learning independently, and communicating independently). To get the overall picture of these sets of data, mean scores were calculated and displayed in Fig. 1.

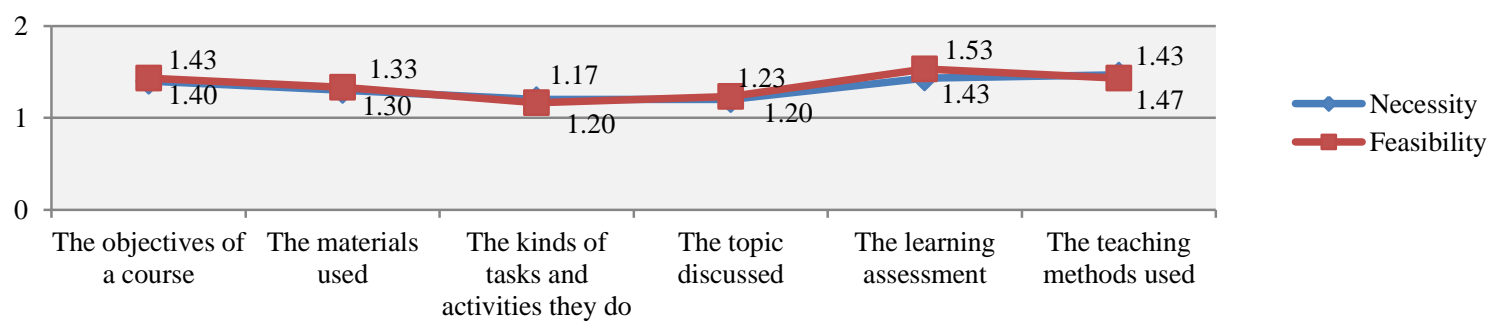

Fig. 1. Necessity and feasibility regarding student involvement in decision-making process (Note: 1: Necessary/Feasible; 2: Unnecessary/Unfeasible)

As displayed in Fig. 1, there was not generally much difference between necessity and feasibility in each item. It can be further viewed that the respondents seemed not to be in favor of necessity and feasibility of student involvement in decision-making about the objectives of the course $(\overline{\mathrm{X}}=1.40 \& \overline{\mathrm{X}}=1.43)$, the learning assessment $(\overline{\mathrm{X}}=1.43 \& \overline{\mathrm{X}}=1.53)$, and the teaching methods used $(\overline{\mathrm{X}}=1.47 \& \overline{\mathrm{X}}=1.43)$. It means that, according to the participants, it was quite unnecessary as well as unfeasible for students to get involved in deciding objectives of the course, learning assessment, and teaching methods. Meanwhile, Fig. 2 showed an obvious difference in terms of mean scores in the first three items: identify their own needs $(\overline{\mathrm{X}}=1.00 \& \mathrm{X}=1.30$,$) ;$ monitor their progress $(\overline{\mathrm{X}}=1.10 \& \overline{\mathrm{X}}=1.30)$; and evaluate their own learning $(\overline{\mathrm{X}}=1.17 \& \overline{\mathrm{X}}=1.33)$.
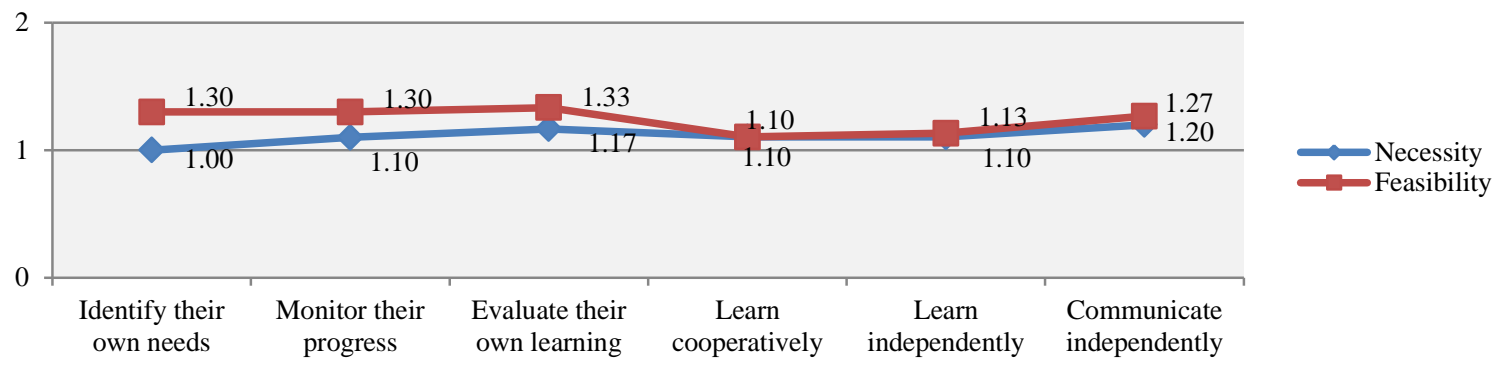

Fig. 2. Necessity and feasibility involving students' ability in monitoring their learning process (Note: 1: Necessary/Feasible; 2: Unnecessary/Unfeasible) 
In addition, Wilcoxon signed ranks test was employed to see whether there were any significant differences between necessity and feasibility in the two sets of ideas. The findings demonstrated that there was no significant difference between necessity and feasibility of student involvement in decisions about the objectives of a course, the materials used, the kinds of tasks and activities they do, the topic discussed, the learning assessment, and the teaching methods used. In other words, there was no gap in the participants' perceptions between necessity and feasibility of student involvement in decision-making process.

However, there were statistically significant differences between necessity and feasibility in the first two items of the second set as presented in Table 2 since p-value of the item "identify their own needs" was .003 and that of the item "monitor their progress" was .034 which were less than .05 . That is, the participants thought that students needed to develop the abilities of identifying their own needs and monitoring their progress, yet it was quite hard for them to do so. Based upon the mean score for feasibility of evaluating their own learning $(\overline{\mathrm{X}}=1.33)$, furthermore, it could be known that the participants thought that it was probably unfeasible for students to evaluate their own learning and did not need to do so. It was because there was no significant difference between its necessity and feasibility.

Table 2. Test statistics of necessity and feasibility of students' ability in promoting learner autonomy

\begin{tabular}{|c|c|c|c|c|c|c|}
\hline & $\begin{array}{l}\text { Identify their } \\
\text { own needs }\end{array}$ & $\begin{array}{l}\text { Monitor } \\
\text { their } \\
\text { progress }\end{array}$ & $\begin{array}{l}\text { Evaluate their } \\
\text { own learning }\end{array}$ & $\begin{array}{l}\text { Learn } \\
\text { cooperatively }\end{array}$ & $\begin{array}{l}\text { Learn } \\
\text { independentl } \\
\mathrm{y}\end{array}$ & $\begin{array}{l}\text { Communicate } \\
\text { independently }\end{array}$ \\
\hline $\mathrm{Z}$ & $-3.000^{\mathrm{a}}$ & $-2.121^{\mathrm{a}}$ & $-1.667^{a}$ & $.000^{b}$ & $-.447^{\mathrm{a}}$ & $-.816^{\mathrm{a}}$ \\
\hline $\begin{array}{l}\text { Asymp. Sig. } \\
\text { (2-tailed) }\end{array}$ & $.003 *$ & $.034 *$ & .096 & 1.000 & .655 & .414 \\
\hline
\end{tabular}

$* p \leq .05$

These findings were somewhat different from the study conducted by Borg and Al-Busaidi (2012). While no significant differences in terms of student involvement in decision-making process between necessity and feasibility were found in this study, there were significant differences in student involvement in the objectives of a course, the learning assessment, and the materials used between desirability and feasibility in Borg and AlBusaidi's (2012) study. However, the results showed significant differences in terms of identifying their own needs and monitoring their progress between necessity and feasibility as Borg and Al-Busaidi (2012) explored.

To sum up, the participants believed that students were unable to make decisions about the objectives of the course, the learning assessment, and the teaching methods. What is more, the abilities of identifying their own needs, monitoring their progress, and evaluating their own learning were assumed not to be feasible for students to develop. This finding was in similar line with some previous research [3], [4]. However, many researchers [7], [11] argue that students must take responsibility for identifying their own needs, monitoring progress, and evaluating the learning process. This may be explained that these abilities, according to Benson (2001), are of cognitive and metacognitive process, thus it was quite complicated for students to develop them. Hence, it can be inferred that in a real class, it is teachers, not students who are responsible for identifying their own needs, monitoring their progress, and evaluating their own learning.

\subsection{Teaching practices in a Thai EFL context}


Teaching activities were comprised of three groups: (i) 'decision-making ability' (activities 1 \& 2), (ii) 'learner independence' (activities 3, 4, 5 \& 6), and (iii) 'psychology of learning' (activities $7 \& 8$ ) as seen in Table 3.

Table 3. Teaching activities

\begin{tabular}{|c|c|c|c|c|c|c|c|c|}
\hline \multicolumn{2}{|r|}{ Activities } & \multicolumn{5}{|c|}{ Frequency of teaching activities $(\%)(n=30)$} & \multirow{2}{*}{ Mean } & \multirow{2}{*}{ S.D. } \\
\hline & & 1 & 2 & 3 & 4 & 5 & & \\
\hline (1) & $\begin{array}{l}\text { Decisions are made on the basis of teacher - learner } \\
\text { agreement and negotiations. }\end{array}$ & 6.7 & 33.3 & 23.3 & 26.7 & 10 & 3.00 & 1.15 \\
\hline \multirow[t]{2}{*}{ (2) } & Learners can make choice about learning materials. & 30 & 33.3 & 26.7 & 6.7 & 3.3 & 2.20 & 1.10 \\
\hline & & & & Total & & & 2.60 & .84 \\
\hline (3) & $\begin{array}{l}\text { Learners are encouraged to develop learning strategies } \\
\text { to achieve their own goals. }\end{array}$ & 6.7 & 30 & 16.7 & 33.3 & 13.3 & 3.17 & 1.20 \\
\hline (4) & Learners develop their own study plans. & 13.3 & 36.7 & 13.3 & 23.3 & 13.3 & 2.87 & 1.30 \\
\hline \multirow[t]{2}{*}{ (5) } & Learners identify their own needs. & 10 & 56.7 & 10 & 10 & 13.3 & 2.60 & 1.22 \\
\hline & & & & Total & & & 2.88 & .90 \\
\hline (6) & Learners evaluate their own learning. & 13.3 & 53.3 & 10 & 23.3 & 0 & 2.43 & 1.00 \\
\hline (7) & Learners reflect on their own learning. & 10 & 33.3 & 26.7 & 20 & 10 & 2.86 & 1.17 \\
\hline \multirow[t]{2}{*}{ (8) } & $\begin{array}{l}\text { Learners monitor their progress in learning English } \\
\text { during the session. }\end{array}$ & 10 & 53.3 & 13.3 & 16.7 & 6.7 & 2.57 & 1.10 \\
\hline & & & & Total & & & 2.62 & .98 \\
\hline
\end{tabular}

Note: 1: Never; 2: Sometimes; 3: Often; 4: Usually; 5: Always; $n$ : Number of participants

The results indicated that the mean scores of the groups $(\overline{\mathrm{X}}=2.60, \overline{\mathrm{X}}=2.88, \& \mathrm{X}=2.62)$ were between 'sometimes' and 'often', i.e., these activities did not frequently happen in the participants' classes. The most frequent activity ( $\bar{X}=3.17$ ) was related to learners' development of learning strategies to achieve their own goals as most of the respondents stated that this activity usually or always happened in their classes. It can be interpreted that the respondents often encouraged students to develop learning strategies. It means that the participants acknowledged the importance of learning strategies for efficient learning as some researchers [10], [12] pinpointed. Meanwhile, several participants rarely gave students opportunities for making choice about learning materials $(\overline{\mathrm{X}}=2.20)$, evaluating their own learning $(\overline{\mathrm{X}}=2.43)$, monitoring their progress $(\overline{\mathrm{X}}=2.57)$, and identifying their own needs $(\overline{\mathrm{X}}=2.60)$. That is, in practice, the participants were unlikely to believe that students could do these tasks.

When asked whether or not the participants gave their students opportunities to develop learner autonomy in their current teaching, two-thirds of the respondents (66.7\%) agreed with this, whereas few respondents (13.3\%) expressed their disagreement and $20 \%$ of the respondents felt undecided about this. That is, students were provided opportunities for developing learner autonomy in most classes. The results indicated that several respondents probably had positive attitude toward learner autonomy, yet there might remain some problems preventing them from promoting learner autonomy in their classes.

In a nutshell, there were three noticeable contradictions between the participants' perceptions and their teaching practices. First, although the majority of participants thought that students could choose their own learning materials, most of them never or sometimes let students make choice about learning materials. Second, all of the participants thought that it was necessary for students to identify their own needs, yet several participants scarcely let students do so as they did not believe that students were able to carry out this task well. 
Similarly, a myriad of participants recognized the necessity of students' ability to monitor their learning progress, but there were few opportunities for students to conduct this task frequently.

\section{Conclusion and recommendations}

Although there are some limitations, e.g., the limited time for conducting the study and the quite small number of the participants, this study yields considerable findings. It can be noticed that the participants generally understand the concept of learner autonomy. Learner autonomy, according to them, means students can choose how and what they learn and monitor their learning progress. However, the participants have encountered difficulties in promoting learner autonomy, which leads to some contradictions between their perceptions and teaching practices. It can be concluded that the participants theoretically acknowledge the concept of learner autonomy, yet it is quite hard for them to implement these issues in practice.

With the hope to promote learner autonomy in this context, some recommendations should be made as follows. Firstly, EFL teachers should be aware of the importance of leaner autonomy so that they can help students gradually become independent learners. They should also get better understanding of the levels of learner autonomy so that they can determine what degree students can possibly assume and then help them develop their autonomy. In addition, they should apply the knowledge about learner autonomy into their teaching. Secondly, administrators should organize seminars or training sessions of learner autonomy for both teachers and students. Especially, how to integrate learner autonomy into language teaching should be widely discussed among teaching staff. Finally, further research should consider to design a model that gradually develops learner autonomy in a real class, to explore potential problems that hinder EFL teachers from developing learner autonomy in teaching practices and to investigate comparison of teachers' and students' perceptions of promoting learner autonomy.

\section{Acknowledgements}

The author would like to express her deepest gratitude to Dr. Sirinthorn Seepho who guided and gave her constructive feedback. Additionally, she also wishes to acknowledge the EFL teachers at the Thai university where this study was undertaken. Without their help as well as willingness, this study would never have been completed.

\section{References}

[1] Al Asmari A. Practices and prospects of learner autonomy: Teachers' Perceptions. English Language Teaching 2013; 6(3):1 10.

[2] Aoki N, Smith RC. Learner autonomy in cultural context: The case of Japan. In Cotterall S, Crabbe D, editors. Learner autonomy in language learning: Defining the field and effecting change, Frankfurt am Main: Peter Lang GmbH; 1999: 19-27.

[3] Bakar NA. Technology and learner autonomy: Teachers' and students' perceptions towards learner autonomy in a computer- based learning environment in a Malaysian context. Proceedings of the independent learning association 2007 Japan conference: Exploring theory, enhancing practice: Autonomy across the disciplines, Chiba: Kanda University of International Studies, 2007.

[4] Balçıkanlı C. Learner autonomy in language learning: Student teachers' beliefs. Australian Journal of Teacher Education 2010; 35(1): 90-103.

[5] Benson P. Teaching and researching autonomy in language learning. England: Longman; 2001.

[6] Borg S, Al-Busaidi S. Learner autonomy: English language teachers' beliefs and practices. Retrieved from http://englishagenda.britishcouncil.org; 2012. 
[7] Little D. Learner autonomy is more than a western cultural construct. In Cotterall S, Crabbe D, editors. Learner autonomy in language learning: Defining the field and effecting change, Frankfurt am Main: Peter Lang GmbH; 1999, pp. 11-18.

[8] Little D. Learner autonomy and the challenge of tandem language learning via the internet. In Chambers A, Davis G, editors. ICT and language learning: A European perspective, Amsterdam: Swets \& Zeitlinger Publishers; 2001, pp. 29-38.

[9] Nunan D. Design and Adapting Materials to Encourage Learner Autonomy. In Benson P, Voller P, editors. Autonomy \& independence in language learning, New York: Longman; 1997, pp. 192-203.

[10] Oxford RL. Toward a more systematic model of L2 learner autonomy. In Palfreyman D, Smith RC, editors. Learner autonomy across cultures: Language education perspectives, New York: Palgrave Macmillan; 2003: 75-91.

[11] Scharle Á, Szabó A. Learner autonomy: A guide to developing learner responsibility. Cambridge: CUP; 2000.

[12] Wenden A. Learner strategies for learner autonomy: Planning and implementing learner training for language learners. New York: Prentice Hall; 1991.

[13] Yıldırım Ö. A Study on a group of Indian English as a second language learners' perceptions of autonomous learning. Turkish Online Journal of Qualitative Inquiry 2012; 3(2): 18-29.

\section{Authors profile}

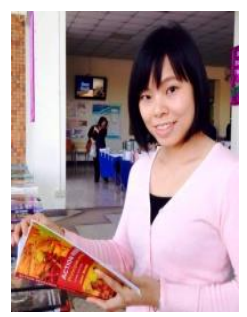

Tham My Duong has been teaching English at Nong Lam University, Vietnam for over nine years. She earned a TESOL Master's degree at University of Social Sciences and Humanities, Vietnam. She has currently been a Ph.D. candidate at Suranaree University of Technology, Thailand. Her research interest includes learner autonomy, TESOL methodology, task-based learning and content-based instruction. Email: duongmythamav@yahoo.com.

How to cite this paper: Tham My Duong,"EFL Teachers' Perceptions of Learner Autonomy and Their Classroom Practices: A Case Study", IJEME, vol.4, no.2, pp.9-17, 2014.DOI: 10.5815/ijeme.2014.02.02 